\title{
Optimismo y realidad en medicina
}

Hope and reality in medicine

Ricci R. Optimismo y realidad en medicina. Evid. Act. Pract.Amb. 2017; 20 (3):64.

La tecnología nos provee de recursos variados que nos desafían a estar a la altura de las circunstancias, como contemplativos y aprendices de la realidad. En mi lector de libros electrónicos "Kindle" tengo la posibilidad de guardar en la carpeta "Mis Recortes", algunas frases que me llaman la atención de las múltiples lecturas habituales. Esas porciones de texto quedan guardadas en la memoria del aparato, disponibles para ser usadas en futuras oportunidades. Algo de eso me ocurrió hoy: me puse a rever Mis Recortes y encontré algunas frases iniciales de un muy potente libro que aún no terminé de leer. Se trata de "Esperanza sin optimismo" de Terry Eagleton ${ }^{1}$. Indudablemente se trata de una obra que amerita un análisis concienzudo de alguien con más capacidades analíticas que las mías. Sin embargo, me voy a atrever a tomar dos o tres frases, con el fin de argumentar en contra del optimismo irreflexivo en la práctica y en la educación médica.

Dados los avances tecnológicos de la medicina, a los que nos referimos de manera machacona y muchas veces injusta; los médicos tenemos con frecuencia la tentación de la omnipotencia, y se las trasladamos a nuestros alumnos de modo naturalmente peligroso. Un joven que ingresa a cursar medicina, puede tener la impresión, a poco de ingresar a los claustros, que el saber médico y los recursos con los que cuenta la medicina hoy en día lo transforman en un potente transformador de las negatividades, al punto de que la enfermedad queda irremediablemente acorralada a la espera de la destrucción definitiva. Naturalmente, la realidad no condice con estas desproporcionadas aspiraciones, por lo que frecuentemente es desoída ya que nos enfrenta a nuestros antipáticos límites.

Al respecto dice Eagleton" en la obra citada "...reconocer la tozudez de la realidad es, en opinión de Erikson, vital para la formación del ego, pero esto es lo que le resulta tan difícil al optimista crónico o profesional..."

Ocurre que, impulsados por algún tipo de viento a favor, no vemos con claridad la realidad y sus límites fácticos. Que por no verla en su plenitud, llena de oportunidades pero también de límites insalvables, seamos seducidos por el optimismo al punto de asistir a la generación de un ego desproporcionado, sin fronteras y por lo tanto lamentablemente endeble. Un ego ficcional, una dramática ilusión. El antídoto para prevenir tal descalabro es la misma realidad, mejor, la descarnada intención de mirar al rostro de la realidad sin tapujos, ni disfraces. La apuesta es mayúscula, de lo genuino de esa interacción surgirá nada más ni nada menos que nuestro ego. Ese yo al que tanto decimos conocer desde toda la vida, pero que sabemos nos esconde numerosos aspectos de nosotros mismos que inevitablemente se manifiestan en nuestros diálogos y acciones cotidianos.

Podemos quedarnos entonces con esta idea: A partir del conocimiento desenmascarado y genuino de la realidad - situación que conlleva no pocas dificultades - podemos asistir comprometidamente al desarrollo de un ego que reconozca (dentro de los límites de factibilidad) sus potencialidades y también sus límites. En la consolidación de una personalidad segura de sí misma y conocedora de sus falencias, tienen mucho que ver aquellos que llevan a cabo la educación del futuro médico. Mucha y mala realidad, puede frustrar a un estudiante de medicina, mucho y malo optimismo, puede deformarlo y transformarlo en un iluso sin remedio. Ambas situaciones resultan catastróficas a la hora que el nuevo médico se ponga en contacto con sus pacientes. Los resultados pueden ser impredecibles. Dicho esto, estemos atentos a la tozudez de la realidad (una piedra es tozudamente dura e impenetrable) de modo que nos ayude en el diseño adecuado de un yo prudente. Un yo que sea sanamente gestor de sus emociones, arrebatos, entusiasmos, límites, razones y debilidades.

Continua Eagleton diciendo que “...un optimista es más bien alguien con una actitud risueña ante la vida simplemente porque es optimista. Prevé que las cosas van a resultar favorables porque él es así. Como tal, no se da cuenta de que hay que tener razones para ser feliz. Por lo tanto, el optimismo profesional no es una virtud, como tampoco lo es tener pecas o pies planos". En suma, que ser optimista no es ninguna virtud, tener esperanza es otra cosa. La actitud risueña ante la vida, si bien hasta puede resultar terapéutica para quien la posee, resulta extremadamente chocante para quien la presencia gratuitamente. El optimista profesional se ríe de nada y por nada. Cada vez que un médico se encuentra con un paciente y toma una actitud risueña ante cualquier intervención del enfermo, se muestra como indiferente y desinteresado. Sólo parece asegurarse su propia impermeabilidad ante el sufrimiento. Según Eagleton el optimista lo es por sí, cree que las cosas van a ser favorables porque él tiene una visión favorable siempre.

Hay que tener una razón para ser feliz. Esta afirmación nos lleva a pensar en instancias existenciales, incluso trascendentes. ¿Acaso hay alguna razón para ser feliz? ¿Una razón que justifique la felicidad humana? Una enorme pregunta, con múltiples respuestas. En realidad con dos básicas: si y no. Las razones para la felicidad pueden estar en la complacencia de la consecución de los propios proyectos vitales, en las interacciones humanas que nos confirman como seres humanos interesados en la suerte de nuestros congéneres, en nuestra mirada de lo trascendente, en nuestra relación con un Dios persona que desgarra el absurdo de la existencia y le otorga su supremo sentido. Sí, hay que tener razones para ser feliz. La felicidad a la que hacemos referencia es aquella que los griegos conocían como eudaimonia. Aquella que Aristóteles entendía como ejercicio virtuoso de lo específicamente humano, es decir, la razón.

¿Qué siempre hay razones para ser feliz? Por ahora no tengo dudas. En el contexto del presente trabajo, deseo advertir acerca de los médicos optimistas profesionales, irreflexivos y negadores de la realidad. Esta última debe consolidarse como la piedra de toque de las previsiones de futuro, como el sustento firme de todo pronóstico cabal. Es la realidad la que nos permite manejar con prudencia el desenfreno de nuestros deseos. Que nuestros alumnos sean conscientes de esto, les permitirá permanecer con los pies en el suelo mientras se ejercitan en los tan necesarios sueños y proyectos de juventud. La virtud está en la observación detenida de la realidad, en el conocimiento de uno mismo y en la prudencia que nos permite calcular con precisión razonable la justicia de nuestros actos.

Finalmente dice el mismo autor que "...tanto el optimismo como el pesimismo son formas de fatalismo". Eso quiere decir que implican falta de libertad, falta de alternativas, carencia de opciones, certidumbre e imposibilidad de torcer los destinos. Esa no es la vida a la que el hombre es invitado. La vida es inestabilidad e incerteza, es acierto y error, es empecinamiento contra la tendencia a la entropía, es indeterminación, emoción y razón, sabiduría y descontrol. Los médicos y nuestros alumnos debemos estar entrenados en la variabilidad, en la sorpresa, en la emergencia de lo nuevo. Debemos desarrollar nuestra profesión abrazados a la capacidad de asombro, preocupados por no perderla nunca y sobre todo por no matarla con nuestro irracional optimismo. 